\title{
THE IMPORTANCE OF THE RELATIONSHIP BETWEEN COMPANY AND INCUBATOR FOR BIOTECHNOLOGY DEVELOPMENT
}

\author{
Ana Paula Ferreira Alves \\ Universidade Federal do Rio Grande do Sul, Brazil \\ E-mail: anapfalves@gmail.com \\ Gabriele Volkmer \\ Universidade Federal do Rio Grande do Sul, Brazil \\ E-mail: gabrielevolkmer@gmail.com \\ Tania Nunes da Silva \\ Universidade Federal do Rio Grande do Sul, Brazil \\ E-mail: tnsilva@ea.ufrgs.br \\ Submission: 08/09/2013 \\ Revision: 26/09/2013 \\ Accept: 01/10/2013
}

ABSTRACT

The biotechnology activities development demands an intense academic and scientific basis, a productive sector capable of transforming academic research in scientific products and services, and the creation of an institutional environment to promote the sector's development. Moreover, many biotechnology companies establish formal partnerships with Universities (by technological incubator) to expand innovative capacity coming into the market. The importance of biotechnology for developing countries is perceived by its ability to promote national development based on knowledge and innovation. In Brazil, the government establishes technological incubators to accelerate the company consolidation. In this way, it is important to study the relationship between the actors involved. In this context, this article aims to analyze the relationship between a technological incubator and a biotech company. To do so, the qualitative approach was adopted to reach the objective. Interviews with incubator's employees of a Brazilian University and biotechnology company's managers were conducted. The results show that the companyincubator interaction promoted projects approval which were able to support new researches development and to purchase production 
INDEPENDENT JOURNAL OF MANAGEMENT \& PRODUCTION (IJM\&P)

http://www.ijmp.jor.br

v. 5, n. 1, October - January 2014.

ISSN: 2236-269X

DOI: 10.14807/ijmp.v5i1.135

equipment. Incubated companies have higher chances of survival in the market from the interaction with University, through the technological incubator. The relationship between the incubator and the biotech company is considered a fundamental condition for biotechnology activities development.

Keywords: biotechnology development, technological incubator, company-incubator relationship.

\section{INTRODUCTION}

The use of sequencing genes technique of living organisms is making significant advances in cellular and molecular biology in the past decades. Such progress allowed the development of biotechnology, which led the biological sciences segment to be considered a business initiative, with the transformation of scientific and technological knowledge into technologies or products. In this sense, biotechnology represents a group of technologies that employ biological basis to make or modify products and processes, as well as to generate new services of high impact on various sectors (BRASIL, 2007). From manipulation of smaller structures that compose living organisms, biotechnology operates, mainly, in the fields of food, energy generation, environmental pollution prevention and bioremediation (ZECHENDORF, 1999).

The biotechnology tools are useful for creating innovations and contribute to a more sustainable development, such as the reduction of pollution in the environment (ZECHENDORF, 1999; VALLE; SANTOS, 2008). Regarding the treatment of contaminated areas, for instance, bioremediation is one of the alternatives more ecologically balanced, with faster results and less costly to industries (ZECHENDORF, 1999). More specifically, bioremediation can be defined as the utilization of living organisms to decontaminate or reduce the pollutants content in the environment (SCHENBERG, 2010).

The importance of biotechnology for developing countries is illustrated by the capacity to promote national development based on knowledge and innovation, generation jobs and supporting economy (VALLE; SANTOS, 2008). Besides that, its applications have contributed to the structuring of new social and economic systems. Therefore, the biotechnology development has strategic importance in the 
consolidation of a knowledge-based economy and sustainable development (BRASIL, 2007). Biotechnology has been pointed as a great new promise to the Brazilian economic development, highlighting the significance of studies in this subject (CUNHA; MELO, 2006).

In this context, there should be a channel between knowledge production and its transformation in product and process, where the result of this articulation is the creation of technological innovations that will provide better conditions for economic and social sustainability (FREITAS et al., 2012). It should be noted that the term innovation involves not only the creation of new products or services in companies, but also the creation of new institutional arrangements between institutional spheres that provide the necessary conditions for innovation (ETZKOWITZ, 2003). Thus, the development of the biotechnology sector requires a complex system of interaction among different agents (large and small companies, universities, research centers, technology incubators, financial institutions, regulators, government, consumers, public agencies) establishing a diversity of integrations due to the cooperation needs and the market competition forms (DRUCK, 2011).

Particularly, technological incubators appear in the convergence of public and private interests seeking to systematize the transition from the development of new technologies to its commercialization, which exemplifies the emergence of a science politics, technology and innovation (ETZKOWITZ, 2002). Therefore, this article aims to analyze the relationship between a technological incubator and a biotechnology company. To achieve this goal, we used a qualitative approach. We believe that is relevant to recognize and to correlate the perceptions around the relationship between the actors involved in order to generate a better understanding about the biotechnology activity development in the country.

This article is divided into five sections, besides its introduction. At first, we performed a review of biotechnology and bioremediation. In the second, we argue about business incubators. In the third, we described the methodology used in this research. The next part presents the analysis of data, structured into categories. Finally, in the fifth part, finals considerations are made as well as study limitations and possibilities for further research. 


\section{BIOTECHNOLOGY}

The term biotechnology can be defined as the science and technology application to the biological basis for change, improve, develop or develop products, process or organisms, as well as to provide services and knowledge production (VAN BEUZEKOM; ARUNDEL, 2009). In other words, the Organization for Economic Cooperation and Development (OECD, 1999) considers biotechnology the application of technical and scientific principles to treatment of materials by biological agents in order to obtain products and services.

Biotechnology is not characterized as a discipline, but presents a complex multidisciplinary basis, where the main subjects are basic science, involving molecular and cellular biology, biochemistry, genetics, microbiology, engineering, chemistry, computer science, among others (CANCHUMANI, 2006; DRUCK, 2011). Thereby, biotechnology is formed by a set of technology skills, produced by scientific and technological knowledge developed in these various disciplines (KREUZER; MASSEY, 2002). Therefore, it is an activity which is characterized by high dependence of research in basic sciences, by multidisciplinarity and complexity, by applying in different production sectors, by high risks involved and by research high costs of its products or services (DRUCK, 2011).

Biotechnology has occupied a prominent role in the world market, since its tools are useful in resolving scientific issues, in developing new products and services, and in achieving goals desired by society (e.g. the pollution reduction in the environment) (ZECHENDORF, 1999; VALLE; SANTOS, 2008). In this sense, it has great potential in the development of more sustainable alternatives, especially in the food, energy production, environmental pollution prevention and bioremediation segments. Biotechnology is able to disseminate new and clean sources of recyclable energy, new methods to detect and treat environmental contamination as well as develop innovative products and processes more environmental friendly compared to the ones used nowadays (KREUZER; MASSEY, 2002). Zechendorf (1999) argues that the application prospects of biotechnological methods are excellent, because these methods are often less expensive than conventional technologies, for instance, in detoxification of effluents.

A biotechnology company is the one that presents technological application, using living organisms as major commercial activity in biological systems or 
processes, in research and development, in the production process or in the provision of services (HODGSON, 2006). Then, Science begins to be understood as a business initiative, from the scientific and technological knowledge transformation into technologies or products. One of the features that differentiate the biotechnology industry - from other high-tech industries - is the activities intensity in research and development, and the period required for an innovation to reach the market. These characteristics forces companies to establish more flexible strategies for innovation, growth and survival (HALL; BAGCHI-SEM, 2001; CANCHUMANI, 2006).

In this context, biotechnology has been used as support for technological innovations, contributing to a high turnover of products in the market, for business competitiveness and socioeconomic development (SCHENBERG, 2010). In Brazil, the Biotechnology Development Policy was approved in 2007 as an initiative to biotechnology activities. This policy aims to provide an environment conducive to creation of innovative biotechnology products and processes, as well as to foster greater efficiency in national productive structure; the increasing capacity to innovate of companies; the study of new technologies; the business generation; and the Brazilian exports expansion (BRASIL, 2007). Biotechnology is, then, presented as a promising opportunity to accelerate national development based on knowledge and innovation, job creation, regional development, increase exports, reduce imports, and clean production with less environmental impact (BRASIL, 2007; VALLE; SANTOS, 2008).

In the past years, the Brazilian scientific community developed a capacity to handling new techniques of biotechnology (e.g., recombinant DNA technology and genomics and proteomics research). Currently, biotechnology integrates the productive base of different national economy sectors, affecting approximately $3 \%$ of gross domestic product (DRUCK, 2011). According to an Overview of Biotechnology in the World and in Brazil, produced by the Brazilian Agency for Industrial Development (ABDI, 2010), the country's Southeast region is responsible for almost half of total national biotechnology research. The Brazilian South region, in turn, owns $23.5 \%$ of the research and overcomes the Southeast concerning the diversity of subjects studied. Still, according to the scenario, $57 \%$ of research in biotechnology is directly financed with funds from the Federal Government $-46 \%$ of these linked to federal universities (ABDI, 2010). 


\subsection{Bioremediation}

An industrialization consequence is the waste release, accidentally or intentionally, improperly in the ecosystem, contaminating the atmosphere, the hydrosphere, the soil and the groundwater and aquifers (WHITE; CLAXTON, 2004; SILVA-JUNIOR; VARGAS, 2007). Among the techniques that are been developed for waste management and areas decontamination, it is possible to apply physical, biological and chemical processes together in order to minimize contamination of organic compounds in security acceptable levels, according to the each country legislation (REDDY et al., 1999). Though, the technique selection varies with the contaminant, the local characteristics, regulatory requirements, operation costs and time constraint (RISER-ROBERT, 1998; REDDY et al., 1999). Khan et al. (2004) say that the choice of effective remediation techniques is complex, however, is crucial to the decontamination success to the impacted area.

Considering that conventional technologies for environmental remediation are generally inadequate to minimize heavy metal concentration in contaminated effluents, bioremediation is presented as an interest alternative (SCHENBERG, 2010). Bioremediation is a remediation technique developed by biotechnology, characterized by presenting a decontamination technique, where the degradation of toxic contaminants is accomplished mainly by the use of microorganisms (that have physiologic and metabolic ability) to degrade such substances (ATLAS, 1981). This phenomenon occurs due to the presence of degrading microorganisms in most ecosystems, where contaminants may serve as a source of organic carbon. Bioremediation uses the physiological competence with degrading potential of these microorganisms. It may be considered as a low-cost-effective and environmentally acceptable alternative (JACQUES et al., 2007).

Bioremediation has several strategies to biodegrade the contaminant on the presence of microorganisms. We can highlight the bio augmentation among them. It is a strategy that helps to improve the capacity of a contaminated matrix in order to remove contaminants by addition of an isolated strain or consortia of microorganisms potentially degrading. The inoculum to be used can be selected directly from the contaminated area, as well as from other impacted environments (FANTROUSSI; AGATHOS, 2005). Gentry et al. (2004) believe that the basic premise for bioaugmentation success, besides the inoculums added to the system, would be the 
metabolic capacity of the population introduced to assimilate the genetic diversity from the contaminated area, leading to an expansion of its biodegradation competence.

In this context, it is clear that biotechnology can assume a very important role, mainly regarding prevention of pollution and bioremediation of contaminated areas. Bioremediation is widely used, comprising degradation of pharmaceutical waste, biotransformation of paper into ethanol, decontamination of mining wastewater contaminated with heavy metals, and oils, among others. Zechendorf (1999) argues that, in 1999, bioremediation already had significant economic efficiency when compared to decontamination traditional technologies, representing a reduction of $65 \%$ to $85 \%$ in the final cost. In fact, bacteria, microalgae, fungi, yeasts, and plants (considering industrial fermentation wastes) can, in principle, serve as a cheap material for water contaminated by metals bioremediation. Also, the aqueous and solid wastes treatment of industrial, agricultural and domestic origin offers a number of opportunities to apply a wide range of bioremediation techniques (ZECHENDORF, 1999).

\section{INCUBATOR}

The biotechnology projects require that companies of this sector conduct ongoing efforts aiming the modernization of productive activities, human resource capacity and accumulation and flow of knowledge from the cooperation with knowledge producing institutes (CANCHUMANI, 2006). The development of biotechnology activities demand a strong academic and scientific basis, a productive sector capable of transforming the academic and scientific production into products and services and the creation of an institutional environment that offers, at the same time, reliability to the entrepreneur and to all society, against the risks involved in investigative and productive activities in the biotechnology field (DRUCK, 2011). Moreover, the institutional environment must provide the necessary conditions to formation of cooperation nets and interaction for generation, transfer and use of knowledge and/or technology. The main motivation for creating these relationships is the complementation technique, since its search is required in activities involving varied and in-depth knowledge (CUNHA; MELO, 2006).

According to Biotechnology Development Policy (BRASIL, 2007), companies currently in the country using biotechnology to develop their technological chain to 
generate their products, process and services rely on technical and scientific support offered by higher education institutes, state institutes, research institutes, active in generation of technologies, goods and biotechnological services. In 2009, Brazil had 108 private biotech companies; most of them had formal partnership with scientific and technological institutions, highlighting the importance of university-industry interaction to expand the innovation capacity that comes to the market (DRUCK, 2011). The universities, research centers, science and technology parks and business incubators begin to act as science business active participants (PISANO, 2006).

From this perspective, Vedovello and Figueiredo (2005) argue that technological business incubators with small and medium companies operating incubated in a productive segment and sharing a similar cultural and socioeconomic environment may constitute a new approach to public policies in favor of innovation and industrial competitiveness. According to the National Association of Promoting Entities of Innovative Enterprises (Anprotec), business incubators are innovative enterprises promoters, aiming to support entrepreneurs so they can develop innovative ideas and transform them into success companies (graduated companies). Some companies, after leaving the incubator, will be creating direct and indirect employment with incomes and assets that will contribute to the economic growth (LALKAKA, 2002) as successful graduated companies. In this sense, the business incubators are playing increasingly important roles in the innovation scenario, bringing together different political and actors, and channeling efforts and resources to promote a more proactive economic environment, supporting a more sustainable and competitive socioeconomic development (VEDOVELLO; FIGUEIREDO, 2005).

Regarding biotechnology, Canchumani (2006) identified that incubators and universities are considered a facilitating factor for formation and development stage of biotech companies. According to the author, incubators and universities are seen by the incubated company owners as training resources for the technological base of companies, both concerning human resources, as technical resources. All companies that were surveyed recognize the importance of research and development, and the cooperation with institutions that produce knowledge, as well as the strategic value of qualified human resources from these institutions. 


\section{METHOD}

This research aims to analyze the relationship between an incubated biotechnology company and a biotechnology technological incubator linked to a University. Thus, it is classified as a qualitative research, which is an exploratory methodology that enables better insight and understanding of the problem context (MALHOTRA, 2006). According to Roesch (1999), the exploratory study is characterized as a research strategy which aims to examine a phenomenon present in its own context. The technological incubator choice was by convenience, because of the access ease to primary data collection. On the other hand, the company's choice was intentional, due to its representativeness to the incubator and in the bioremediation field. The company is incubated since its formation in 2003, and even beyond the incubation period, the company maintains its status as incubated, as well as projects with the incubator and the University.

Interviews were performed as data collection technique, and developed with aid of a semi-structured script with open questions. The script had questions about the interaction between University-company, the relation between incubator and incubated and from the perspective of biotechnology activity in the country for the next years. The initial contact with the incubator happened on a technical visit. After this visit, we conducted the interview with the technological incubator manager, who provided information about the incubated company. Later, we get in touch with the company by telephone in order to invite their managers to participate of this study. The interviews were conducted at the company administrative department.

The incubated company administrative and financial manager, the marketing manager and the production manager were interviewed, as well as the incubator manager. The interviews were granted in June/July 2012, and each one lasted approximately 30 minutes. The interviews were recorded by audio recording and then, they were transcribed. After these procedures, we used the technique of content analysis for data processing. The data collected in the interviews are reported and compared with the literature chosen. To preserve the incubator and the company identities, we chose to use fictitious names on the results analysis. So, the participants were called as $\mathrm{G} 1, \mathrm{G} 2, \mathrm{G} 3$ and G4 to preserve their identity, where $\mathrm{G} 1$, G2 and G3 represent the incubated company and G4 the incubator. 


\section{RESULTS}

\subsection{The biotech company}

The studied company develops and sells biotechnology based products as an alternative to the treatment of municipal and industrial sewage, animal manure and domestic sewage. Biosul (a fictional name) has a collection of over 2,000 selected microorganisms isolated and identified. Associated with knowledge and domain on conducting biotechnological production processes, these are their greatest asset and differential. The company is located in Southern Brazil and it distributes its product in Brazil, Argentina and Spain. Biosul was founded in 2003 originated from PhD thesis, in order to apply the biotechnology concepts in practice, as well as bring scientific knowledge to everyone. Since its foundation, the company is tied to a technological incubator from a Federal University. By the relationship with the incubator, it has submitted and approved projects to support research and development of new studies, and to purchase machinery and equipment to the new production process.

Nowadays, Biosul has five employees in it staff, working directly at the company headquarters, plus a net of distributors and technical assistance spread in Brazil and in the foreign countries. Considering staff, the managers interviewed are: administrative and financial (G1); production (G2); and, marketing (G3). G1 is the Biosul founder and he has Ph.D. in cellular and molecular biology. G2 is studying Ph.D. in biotechnology developing a product for contaminates soil by hydrocarbons treatment. G2 is a company employee since 2009. G3 is a chemical technician, with degree in chemistry and management. G3 is company employee since 2005; since 2008, G3 is also a Biosul partner.

At this point, it is possible to notice that employees have a career in biotechnology, in academic research or market research, and professional experience involving environmental impacts minimization through biological treatment. This trajectory can justify employees identification with the company goals. As the speech of G3, "I see the company today, we got this structure, setting up a new team and we see a huge potential [...] I believe in the product and see opportunities to the company." G2 claims that he has pretentions to continue working on Biosul, as we can see in this interview passage: "the company has a small staff, but we cheer for this team to grow and continue to be a team part". 
Biosul products reduce the degradation time of contaminated areas, without releasing chemicals in the environment (as observed in traditional remediation techniques). According to G2, "what you have is more chemical [...] it can be used but, sooner or later, may cause damage. Bioremediation is a clean technology of remediation". Unlike other bioremediation companies, Biosul products are developed using microorganisms from the native biota. Such fact can be confirmed from the report of G2: "hence, we always try to work with local microorganisms, so there is no damage when it is added to the environment".

The use of Biosul's products accelerates the waste degradation, reducing the degradation time, minimizing the costs and, consequently, generating greater affordability to their customers. The technical assistance available from the product purchase is highlighted as a fundamental element of the company's strategy, since it is necessary to make the application accurately and follow up the residue degradation. This fact is corroborated by G3: "the analysis that we follow is a job that requires $100 \%$ of post sales; it [the bioremediation] is the kind of job that monitoring is essential to make it work". Therefore, orientations are made to customers so they can understand how the product works. Distributor's teams are spread in the country and they are trained to pass this information to customers, as well as to know how to evaluate the products results.

\subsection{The Incubator}

The technological incubator of biotechnology (TIB) is located in the Brazil Southern region and it is linked to a Federal University. The TIB started its activities in 1992, with two incubated companies. In a general way, TIB seeks to establish, develop and strengthen small business and technological projects in biotechnology and related sectors. The incubator goal is to stimulate the creation and strengthening of companies, offering a suitable environment and promoting technical and managerial skills, by training and teaching activities of human resources highly qualified in their areas. The TIB is installed within the University, designed to stages of development and production up to eight companies incubated simultaneously. Also, the incubator offers a meeting room for shared use and an amphitheater with capacity for 115 guests.

The incubator installation at the University promotes potential research activities as job and resources generators encourage new companies in the 
biotechnology segment by furthering interaction among University and companies, create jobs, train human resources, and promote the direct connection between scientific and technologic development with its incorporation to production means. Furthermore, the incubator has a team, coordinated by a university teacher and managed by a university employee (G4). It also has a secretary, internships and external consultants. G4 has a degree in biology and, since 2000, works directly at incubator. About the beginning of the incubator, G4 says:

\footnotetext{
"it was a year [reference to 2000] of courses and selections, business plan course, management techniques, visits to incubators, strategies, planning, and they select 10 employees that could be reallocated to the management of the University's incubator and to support technology transfer issues, so I went to the biotechnology incubator".
}

The company incubation process has three steps: selection of companies, pre-incubation and incubation. Periodically, the incubator opens a call for companies to select those who will join the incubation process. These candidates must prepare a business plan submitted with proper documentation for proposal submission to the incubation call. After analyzing the business plan, the approved one joins the TIB for the pre-incubation phase. The pre-incubation is intended to improve the business plan, with support from the incubator, and to formally build the biotechnology company. G4 explains that, during this phase, the entrepreneur "spends six months with our consultant, consulting one hour per week, and the guy will be focused on those parts of the business plan that required more attention, needed more information. He will learn how to make a market assessment and how to use financial spreadsheets".

At the end of pre-incubation phase, the business plan is assessed in terms of its technical, economic and market feasibility and moves to the incubation phase (or the company will be disconnected from the incubator). G4 says: "at the end of six months if [ ] the business viability is proven with as much data as possible and the company was created, because it needs a national register of legal person, then [the entrepreneur] signs the incubation contract". During the incubation phase, the company develops, produces and sells its products. The incubation time is tree years, and it can be extended for more three years. This time is longer than the incubation time of other incubators, however, according to G4, "who knows some incubator will say [ ] six years, this is nonsense! Actually, it is not. If you think that in 
biotechnology sector, the average time to get into the market is about ten years, six years is nothing extraordinary. In some cases, we have to extend it a little bit."

Currently the TIB has eight companies incubated and it is preparing a call to select four projects. The incubated companies operate in the health segment, agribusiness and environment. The services offered by TIB to incubated companies includes: support to prepare the business plan; orientation for seeking funding and research and development project management; business management consulting; training for specialized technical development; assistance in finding new technologies; encourage on interaction with external sources of capacity and knowledge; access to laboratories of the University's biotechnology center; and, supportive administrative services, such secretarial, reception, internet access and cleaning services. Moreover, G4 complements: "we [the incubator] are now seeking the certification for business incubators [ ] today are a few hundred items that are selection, evaluation, a series of items, business plan that the incubator has to be structured. This certification will give a minimum quality pattern to incubators".

\subsection{Analysis and Interpretation}

Using the content analysis technique, some elements were identified from respondent's reports. These elements are considered most relevant and frequent to the studied circumstance: the interaction between University and company; the relation between the incubated company and the technological incubator; the government role in the biotechnology development; and, the biotechnology sector perspective in the country for the next years. Business incubators had become incorporated into Brazil policy agenda from the late 1980s and the beginning of the 1990s (VEDOVELLO; FIGUEIREDO, 2005). The Federal University linked to the studied incubator has others incubators divided into sectors. The proximity to specific laboratories of each sector allows a greater synergy among staff training, the research and the incubated companies. G4 explains that in early 1990s,

"the University realized that there was a trend of sectorial incubators [ ], the biotechnology incubator was being created, the computing one, the medicine one, the University was structuring its strategy of incubators, with normalization of the University so each one won't make different things. Why results are better in terms of sectorial incubators? Because, in biotechnology, I have to offer a laboratory module, I have to consider the characteristics of biotechnology. So the incubator being sectorial suits better for the incubated company. So, we can work better for characteristics of the sector". 
Also, G4 states: "the incubator was created especially because the interaction lack between the biotechnology center and the productive sector". This statement confirms the argument from Valle and Santos (2008). Those authors pointed out that the biotechnology development demands a strong academic and scientific base creation as well as a productive sector capable of transforming this academic and scientific production into goods, processes and services. From this perspective, it is understood that the TIB has the goal of facilitating the integration of the products, processes and services that were developed in biotechnology researches in the University with the biotechnology industry. According to G4: "our incubator's mission is to fund and support the development of biotechnology companies, where the business matter comes... That's the reason why it exists and works until today".

The interaction University-company is shown as an essential condition for the biotechnology activities development by company managers. G3 argues: "the interaction with the University ends up being beneficial to the company, the fact of being a company with the University helps with credibility, especially for a startup, with a new service in the market, it is important to have this support". G2 complements saying: "information is critical, what is happening, trends, on the innovation field, everything goes through the University, so it is good to have this bond. And the University is very well regarded". Accordingly, from the reports, it is possible to notice that the incubator aims to assist and support the incubated companies in product development and in the company's organization itself.

Biosul maintains patents for its products with the University. Pisano (2006) says that much of the interaction discussion between universities and biotechnology industries is about the patents, when, in fact, the central issue should be the knowledge in this patent. The main problems caused by the technological development of companies focus on the difficulty of managing the knowledge inherent on research activities (CUNHA; MELO, 2006). Still, the authors suggest that the incubators should encourage the creation and development of companies through the further entrepreneur training in their technical and managerial aspects. G4 indicates: "entrepreneurs [from biotechnology companies] are good technically, but they don't know how to sell the product, or even how to approach a customer, nothing about finances, or market, they don't know how to do it". Further, G4 complements: 


\begin{abstract}
"the entrepreneurship at the University begins with someone [the entrepreneur] having a good idea, but we have to elaborate it. There is a strategy for each level. This person has to make a business plan, the University has a program that teaches how to do it, he has consulting, he will reach the end, with a business plan, then he can go to an incubator where he will develop that business plan, where he will use the research and development laboratory. He will be around the place where innovation happens; he got a better success chance this way."
\end{abstract}

In this way, we can verify that incubated companies have higher chances of survival in the market from the interaction with University, through the incubator, as reported by G1: "outside the incubator is complicated. The biotechnology interaction with the University is essential". In turn, G2 comments: "we had support from economists, consultants, business plan; they taught us how to do it. I used to work only on research and after this training I learned from how to issue a note to how manage the company". The Biosul managers agreed that incubation was necessary for their company and for products development. The incubated company performance can be improved by the existence of a services package and financial resources provided to or by technological incubators (VEDOVELLO; FIGUEIREDO, 2005). G1 ensures: "the company incubation is necessary, [ ] so biotechnology won't develop outside the incubator, it simply does not happen".

It is possible to notice that company incubation is essential due to some characteristics of the sector, such as high costs of research and commercialization of products or services, necessity of qualified people, and necessity of adequate infrastructure. G4 exposes: "the sector characteristics are: 'the high costs of equipment, long developing time, also the physical areas that need to be appropriate to the operations'". From the recognition of the sector characteristics, G4 adds that "this [the sector characteristics] we as incubators need to know, the hardest bottlenecks for companies, we as incubators need to attend".

Due to the high cost to create and structure the company and the product maturation period, G1 claims: "biotechnology grows slowly, because biotechnology demands a lot of research and very expensive equipment". This report is supported by Canchumani (2006), because the author considers the consolidation of biotechnology companies on the market slow. Hall and Bagchi-Sem (2001) follow the same line by state that one of biotechnology industry characteristics is the long period required for the innovations developed in research laboratories come available in the market. Thus, G1 ensures: "the researches in biotechnology could last 15 
years until it results in a product [...] the incubation time has to be bigger too". G4 reinforces: "10 years is, in average, the normal time for biotechnology, but the incubator has the function to accelerate the processes. So, if everyone works straight, it is possible to develop in less time".

According to Vedovello and Figueiredo (2005) and Lalkaka (2002), the incubators must provide to companies a proper infrastructure and a supportive environment needed to foment new ventures. The studied incubator is located in a permanent spot inside the University. There are labs for products research and development, meeting rooms, reception room, as well as rooms for the administrative sector of each incubated company. G1 says that this infrastructure facilitates the biotechnology activities development, since "public universities are well structured and got more equipment already". However, the incubators should not be considered just as a shared enterprise space, but as people and organizations nets (HACKETT; DILTS, 2004).

Regarding human resources, G4 informs that incubated companies entrepreneurs are highly educated, " $80 \%$ has masters or Ph.D. degree, and the team is not composed $100 \%$ of doctors because the ones with master degree are still studying for Ph.D., but it is really an entrepreneur with high qualification". Nonetheless, the Biotechnology Panorama in the World and in Brazil (ABDI, 2010) has pointed bottlenecks related to attracting and fixing those professionals to the sector, including low wage and incipient training in management. This fact can be explained by G1's report: "the researches have to keep up. After finishing the Ph.D., it is very hard to develop a product, so they have to find other ways to make money. They end up not being able to develop the product and abandon it [the idea]". Biosul emerged from the G1's Ph.D. thesis, and it only managed to grow because, as G2 said, "it was born incubated".

The company's relationship with the University is extremely important. According to G4, "given the number of companies, there is low number of employees for companies involved with biotechnology". G2 states: "most of the staff working with us [at Biosul] came from there [the University]. It is a proof". G3 tells that he is doing his Ph.D. in biotechnology area, and got a project approved linking his job and his studies. G2 claims: 
"when Biosul leaves the incubator, we want to keep the research and development with the University, because the University is the best source for information and human resources. The connection with the incubator and the University allows our company to submit projects to finance machinery, equipment, supplies, researches, human resources etc."

Regarding incentives, the government has provided significant amount of resources to promote the research and development in biotechnology, through agencies as the Coordination of Improvement of Higher Education Personnel (CAPES), the National Council of Science (CNPq) or another governmental agency. According to G2, "all equipment was acquired through public money, using projects". The resources devoted to research and development in biotechnology were, somewhat, sufficient. However, according to G3, "if you look the calls, resources aren't for bioremediation. It is for other biotechnology areas... biotechnology sometimes is focused on cellular and molecular biology, nanotechnology, transgenic. Nowadays, the environmental treatment is still unknown".

Moreover, the relationship with governmental agencies as pointed as paradoxical, because it presents lots of incentives and, at the same time, innumerous obstacles. It should be noted that one of the Biotechnology Development Policy objectives established in 2007 includes "the establishment of appropriate environment for the development of innovative biotechnological products and processes" (BRASIL, 2007, Art. $1^{\circ}$ ). Nonetheless, G1 says:

\footnotetext{
"the relation with the govern is paradoxical. At the same time that they give a lot of resources for research and development for biotechnology, the State structure forbids the commercialization, there is no normative, no regulation for our biological products [...] at the same time everyone thinks that it is genius to use biotechnology to develop the country, there is no legislation for it, and that prevent us to sell what we produce".
}

The main difficulties identified to biological products development were the laws related to products manufacture and commercialization. The animal, industrial wastewater and sanitary and domestic areas force the company to comply the legislation of three environmental government agencies: Agriculture, Livestock and Supply Ministry (MAPA), Health Surveillance National Agency (ANVISA) and the Environment and Renewable Natural Resources Brazilian Institute (IBAMA). According to $\mathrm{G} 1$,

"the legislations are conflicting, because IBAMA demands some tests to approve the product while ANVISA demands others. So? IBAMA claims that if you do not register it with them, you cannot sell. ANVISA claims that registering it with them, allows you to sell. The legislation for biological products is the biggest obstacle in this country". 
The respondents maintain a positive view when asked about the expectation of biotechnology activity in Brazil, as $\mathrm{G} 1$ says: "the future is very promising". G3 says: "biotechnology is an area that will grow a lot in this country". This argument can be justified by the Biotechnology Development Policy. This Brazilian legislation aims to provide appropriate conditions to the development of innovative biological products, processes and services (Brasil, 2007). Concerning bioremediation, G3 claims: "the bioremediation is still unknown, but it is getting better. There is always a new project with governmental funds to biotechnology. I think that this segment is growing and has huge potential". G2 says that the segment future belongs to the ones that are studying at the University and that put their ideas into practice, betting that it will come true in the incubated companies. He adds that for the biotechnology activity development, "we must take the knowledge to everyone, the scientific knowledge, to really perform applied biotechnology".

\section{FINAL CONSIDERATIONS}

This article aimed to analyze the relationship between the technological incubator and a biotech company. To this end, we conducted interviews with the coordinator of a technological incubator for biotechnology sector and managers of a biotechnology company incubated. It was found many gaps in scientific knowledge production and biotechnology application, since biotech companies face technicalscientific, productive, financial or commercial problems that still cannot be fully solved. However, respondents agree that the incubator represents a possibility to overcome these gaps and ensure greater longevity for the company in the market. The relationship between Universities and biotechnology companies is considered a fundamental condition for development of these activities, due mainly to high initial capital necessary for company's opening and the long time required developing the product.

The technological incubator represents a notorious way for Biosul to keep in touch with the Federal University. This institution is an important source of information, trends, innovations and human resources. Respondents stated that the connection with the University allowed the company to submit and approve projects to support and develop new researches as well as to purchase machines and equipment for production process. However, it was considered consensus that government agencies stimulate the research and biotechnology development, and, at 
the same time, end up creating barriers and contradictions for companies in this sector. Furthermore, it was found that the main obstacles to create biotechnology companies are difficulty in raising resources, lack of infrastructure necessary to manufacture the products, government heavy regulation and lack of skilled managers.

We believe that the sample size is the central limitation of this research. Data collected represents only views, opinions and perceptions of the respondents. Thus, other participants from other companies in the biotechnology industry and other technological incubators could assign different answers to the questions. Therefore, this study does not intend to generalize the achievements. For future research, we suggest researching the opinions and the perceptions of a larger number of experts; to analyze the relationship of incubators and incubated companies in other regions of Brazil or other countries; to interview experts from other knowledge areas; or still, to analyze publication level in national and international journals to verify if there is indeed a research increase on the topic.

\section{REFERENCES}

AGÊNCIA BRASILEIRA DE DESENVOLVIMENTO INDUSTRIAL (ABDI) (2010). Panorama da Biotecnologia no Mundo e no Brasil. Available from: <http://www.abdi.com.br/Estudo/Panorama\%20Setorial\%20Biotecnologia.pdf>. Accessed in 2012 Jun 25.

ANPROTEC (2012). Associação Nacional de Entidades Promotoras de Empreendimentos Inovadores. Available from: <http://anprotec.org.br/site/incubadoras-e-parques/>. Accessed in 2012 Jul 29.

ATLAS, R. M. (1981). Microbial Degradation of Petroleum Hydrocarbons: an Environmental Perspective. Microbiological Reviews, v. 45, n. 1, p. 180-209.

BRASIL. Ministério da Ciência e Tecnologia (2007). Política de Desenvolvimento da Biotecnologia. Decreto $n^{\circ}$ 6.041. Brasília. Available from:

$<$ http://www.mct.gov.br/upd_blob/0016/16386.pdf>. Accessed in 2012 Jun 29.

CANCHUMANI, G. A. L. (2006). Capacidades Tecnológicas de Empresas de Biotecnologia: o estudo de quatro casos. Dissertation (Masters in Business Administration). Porto Alegre: UFRGS.

CÔRTE-REAL, M. (2002). Perfil da Indústria Brasileira de Biotecnologia focado nas Relações com o Mercado. Porto Alegre: AGE.

CUNHA, C. R., MELO, M. C. O. L. (2006). Confiança nos Relacionamentos Interorganizacionais: o campo da biotecnologia em análise. RAE-eletrônica, v. 5, n. 2, art. 18, jul./dez.

DIAS, V. V., MENEZES, U. G., PALMA, E. P., GROHMANN, M. Z. (2009). A percepção dos gestores sobre as ações de sustentabilidade e sua relação com as 
estratégias organizacionais. In: XI ENCONTRO NACIONAL E I ENCONTRO INTERNACIONAL SOBRE GESTÃO EMPRESARIAL E MEIO AMBIENTE. Proceedings... Fortaleza: ENGEMA, 2009.

DRUCK, S. (2011). Quem é Quem em Alimentação, Agricultura, Pesca e Biotecnologia: competências e pesquisas desenvolvidas no Brasil. Brasília: IBICT. Available from: <http://bbice.unb.br/media/publicacao/6f0a49f71e99541baff8e51e467ff281.pdf> Accessed in 2012 Jun 27.

ETZKOWITZ, H. (2002). Incubation of incubators: innovation as a triple helix of university- industry-government networks. Science and Public Policy, v. 29, n. 2, p. $1-14$.

ETZKOWITZ, H. (2003). Innovation in innovation: the triple helix of universityindustry-government relations. Social Science Information, v. 42, n. 3, p. 293-337.

FANTROUSSI, S., AGATHOS, S. N. (2005). Is bioaugmentation a feasible strategy for pollutant removal and site remediation? Current Opinion in Microbiology, v. 8, n. 3, p. 268-275.

FREITAS; C. C. G., MAÇANEIRO, M. B., KUHL, M. R., SEGATTO, A. P., DOLIVEIRA, S. L. D., LIMA, L. F. (2012). Transferência tecnológica e inovação por meio da sustentabilidade. Revista de Administração Pública - RAP, v. 46, n. 2, p. 363-84, mar./abr.

GENTRY, T, RENSING, C., PEPPER I. L. (2004). New Approaches for Biosegmentations a Remediation Technology. Critical Reviews in Environmental Science and Technology, v. 34, n. 5, p. 447-494.

HACKETT, S., DILTS, D. (2004). A Systematic Review of Business Incubation Research, Journal of Technology Transfer, v. 29, p. 55-82.

HALL, L, BAGCHI-SEM, S. (2001). An Analysis of R\&D, innovation and business performance in the US biotechnology industry. Internacional Journal of Biotechnology, v. 3, n. 3.

HODGSON, J. (2006). Private biotech 2004 - the numbers. Nature Biotechnology, v. 24, n. 6, jun.

JACQUES, R. J. S., BENTO, F. M., ANTONIOLLI, Z. I., CAMARGO, F. A. O. (2007). Biorremediação de solos contaminados com hidrocarbonetos aromáticos policíclicos. Ciência Rural, v. 37, n. 4, p. 1192-1201.

KHAN, F. I., HUSAIN, T., HEJAZI, R. (2004). An Overview and Analysis of Site Remediation Technologies. Journal of Environmental Management, v. 71, n. 2, p. 95-122.

KREUZER, H., MASSEY, A. (2002). Engenharia genética e biotecnologia. Porto Alegre: Artmed.

LALKAKA, R. (2002). Technology business incubator to assist a innovation based economy. Journal of Change Management, v. 3, n. 2, dec.

MALHOTRA, N. K. (2006). Pesquisa de Marketing: Uma orientação aplicada, 4 ed. Porto Alegre: Bookman, brazilian translation in 2006. 


\section{ORGANISATION FOR ECONOMIC CO-OPERATION AND DEVELOPMENT} (OECD) (1999). Modern Biotechnology and the OECD. OECD Paris: Policy Brief OECD, June.

ORSATO, R. J. (2006). Competitive Environmental Strategies: when does it pay to be green? California Management Review, v. 48, n. 2, p. 127-143.

PISANO, G. P. (2006). Can Science Be a Business? Lessons from Biotech. Harvard Business Review, oct.

REDDY, K. R., ADMAS, J. F., RICHARDSON, C. (1999).“Potential technologies for remediation of Brwnfield. Practice Periodical of Hazardous, Toxic, and Radioactive Waste Management, v. 3, n. 2, p. 61-68.

RISER-ROBERTS, E. (1998). Remediation of Petroleum Contaminated Soil: biological, Physical, and Chemical Processes. Boca Raton (FL): Lewis Publishers, Boca Raton.

ROESCH, S. M. (1999). Projetos de estágio e de pesquisa em administração, 2 ed. São Paulo: Atlas.

SCHENBERG, A. C. G. (2010). Biotecnologia e desenvolvimento sustentável. Revista de Estudos Avançados, São Paulo, v. 24, n. 70.

SILVA-JUNIOR, F. M. R., VARGAS, V. M. F. (2007). Avaliação de áreas de influência de uma termelétrica a carvão através de ensaio de genotoxicidade. Journal Brazilian of Ecotoxicology, v. 2, n. 2, p. 197-199.

VALLE, M. G., SANTOS, M. S. (2008). A biotecnologia como instrumento de desenvolvimento econômico e social. Universidade de Relações Internacionais (Brasília), v. 6, n. 1, jan./jun.

VAN BEUZEKOM, B., ARUNDEL, A. (2009). OECD Biotechnology Statistics 2009. Paris. Available from: <http://www.oecd.org/dataoecd/4/23/42833898.pdf> (accessed in 2012 Jun 29).

VEDOVELLO, C., FIGUEIREDO, P. N. (2005). Incubadora de Inovação: que nova espécie é essa? RAE-eletrônica, v. 4, n. 1, jan./jul.

WHITE, P. A., CLAXTON, L. D. (2004). Mutagens in contaminated soil: a review. Mutation Research, v. 567, n. 2-3, p. 227-345.

ZECHENDORF, B. (1999). Sustainable development: how can biotechnology contribute? Trends in Biotechnology, jun. 